\title{
Lanthanum improves the cadmium tolerance of Zea mays seedlings by the regulation of ascorbate and glutathione metabolism
}

\author{
H. DAI ${ }^{1,2,3}$, C. SHAN ${ }^{4,5 *}$, H. ZHAO ${ }^{2}$, G. JIA ${ }^{6}$, and D. $\mathrm{CHEN}^{1}$ \\ Bio-Resources Key Laboratory of Shaanxi Province ${ }^{1}$, College of Biological Science and Engineering ${ }^{2}$, \\ Shaanxi University of Technology, Hanzhong 723001, P.R. China \\ Qinling-Bashan Mountains Bioresources Comprehensive Development Collaborative Innovation Center, \\ Hanzhong 723001, P.R. China ${ }^{3}$ \\ Henan Institute of Science and Technology, Xinxiang 453003, P.R. China ${ }^{4}$ \\ Collaborative Innovation Center of Modern Biological Breeding, Henan Province, Xinxiang 453003, P.R. China \\ College of Science, Northwest Agriculture and Forestry University, Yangling 712100, P.R. China ${ }^{6}$
}

\begin{abstract}
The effect of lanthanum on the metabolism of ascorbate (AsA) and glutathione (GSH) in the leaves of maize seedlings under cadmium stress was investigated. The findings showed that $\mathrm{Cd}$ remarkably increased electrolyte leakage (EL), the activities of ascorbate peroxidase, dehydroascorbate reductase, monodehydroascorbate reductase (MDHAR), glutathione reductase, L-galactono-1,4-lactone dehydrogenase, and $\gamma$-glutamylcysteine synthetase, and the content of reduced AsA, reduced GSH, total AsA, total GSH, malondialdehyde (MDA), and Cd, compared with control. However, $\mathrm{Cd}$ significantly decreased the dry biomass of roots and shoots. Treatment with $\mathrm{La}+\mathrm{Cd}$ evidently increased the activities of above enzymes except MDHAR, the content of reduced AsA, reduced GSH, total AsA and total GSH, and the dry biomass of roots and shoots, compared with $\mathrm{Cd}$ stress alone. Meanwhile, treatment with $\mathrm{La}+\mathrm{Cd}$ remarkably decreased EL and the content of Cd and MDA compared with Cd stress alone. Our results suggested that La could be used as a regulator to improve the $\mathrm{Cd}$ tolerance of maize for its role in the alleviation of Cd-induced oxidative damage by regulating the metabolism of AsA and GSH.
\end{abstract}

Additional key words: ascorbate peroxidase, electrolyte leakage, glutathione reductase, maize, malondialdehyde.

\section{Introduction}

Cadmium is a heavy metal with high toxicity and exists widely in environment (Naija et al. 2016). It is absorbed by plants and its accumulation induces the overproduction of the reactive oxygen species (ROS) which can exceed the capacity of ROS-scavenging system and result in oxidative damage to plants (Wu et al. 2015). To protect against the oxidative damage, plants have a defense system including antioxidant enzymes and non-enzymatic antioxidants (Daud et al. 2016).

Ascorbate (AsA) and glutathione (GSH) are two important non-enzymatic antioxidants. Their content in plants can be regulated by phytohormones such as jasmonic acid (Shan and Liang 2010). Lanthanum is an important rare earth element. In plants, La has many roles in regulating the growth and development, root organogenesis (Guo et al. 2012), seed germination (Hong et al. 2003), and secondary metabolism (Zhou et al. 2012). Further, $\mathrm{La}$ can improve the $\mathrm{NaCl}$ and $\mathrm{Cd}$ tolerance of plants by enhancing the activities of antioxidant enzymes (Xu et al. 2007, Wang et al. 2012,

Submitted 25 February 2016, last revision 9 May 2016, accepted 3 August 2016.

Abbreviations: APX - ascorbate peroxidase; AsA - ascorbate; DHAR - dehydroascorbate reductase; $\gamma$-ECS - $\gamma$-glutamylcysteine synthetase; GalLDH - L-galactono-1,4-lactone dehydrogenase; GR - glutathione reductase, GSH - glutathione, MDHAR monodehydroascorbate reductase; ROS - reactive oxygen species.

Acknowledgements: Our study was funded by the Starting Fund for High-level Talents (Doctor) of Henan Institute of Science and Technology (2011010), the Natural Science Foundation of Shannxi Province (2015JM3086), and the Foundation of Gansu Key Laboratory of Biomonitoring and Bioremediation for Environmental Pollution (GBBL2015006) and the Comprehensive Development, Collaborative Innovation Center (QBXT-Z(P)-15-7).

* Corresponding author; e-mail: shchjuan1978@aliyun.com 
Shan and Zhao 2014). However, whether La regulates the regeneration and biosynthesis of AsA and GSH in plants under $\mathrm{Cd}$ stress remains unclear.

The aim of this study was to elucidate whether La regulates the metabolism of AsA and GSH in maize seedlings under Cd stress and to provide new knowledge for the possible application of $\mathrm{La}$ in agriculture to alleviate the effect of $\mathrm{Cd}$ on the growth of maize.

\section{Materials and methods}

Seeds of maize (Zea mays L.) cv. Xindan29 were germinated and grown in distilled water in artificial climate chamber under day/night temperatures of $25 / 15{ }^{\circ} \mathrm{C}$, a relative humidity of $65 \%$, and a 10 -h photoperiod with a photosynthetic active radiation of $500 \mu \mathrm{mol} \mathrm{m} \mathrm{m}^{-2}$. When the first leaf was fully expanded, the seedlings were transferred into plastic boxes filled with half-strength Hoagland's nutrient solution and kept their roots in the dark. The Hoagland's solution was exchanged every two days. When the third leaf was fully expanded, the roots were placed in beakers containing $100 \mathrm{~cm}^{3}$ of $80 \mu \mathrm{M} \mathrm{CdCl}$ solution for $48 \mathrm{~h}$. The $\mathrm{CdCl}_{2}$ solution was prepared by adding $\mathrm{CdCl}_{2}$ into Hoagland's solution. To select a suitable concentration of lanthanum, the effects of $0,10,30,60$, and $90 \mu \mathrm{M} \mathrm{LaCl}{ }_{3}$ on the content of reduced AsA, total AsA, reduced GSH and total GSH in leaves of maize seedlings were investigated. The $\mathrm{LaCl}_{3}$ solution was prepared by adding $\mathrm{LaCl}_{3}$ into Hoagland's solution. To study the effect of $\mathrm{La}$ on the metabolism of AsA and GSH under $\mathrm{Cd}$ stress, the seedlings were pretreated with $30 \mu \mathrm{M} \mathrm{LaCl}_{3}$ (a suitable concentration selected from above five concentrations) for $12 \mathrm{~h}$ and then exposed to Cd stress for $48 \mathrm{~h}$. Control seedlings were treated with Hoagland's solution alone. After treatment for 24 and $48 \mathrm{~h}$, the third leaf of maize seedlings was collected to analyze the electrolyte leakage (EL), the activities of enzymes in the metabolism of AsA and GSH, and the content of reduced AsA, total AsA, reduced GSH, total GSH, and malondialdehyde (MDA).

Ascorbate peroxidase (APX; EC 1.11.1.11), glutathione reductase (GR, EC 1.6.4.2), dehydroascorbate reductase (DHAR, EC 1.8.5.1), and monodehydroascorbate reductase (MDHAR, EC 1.6.5.4) were extracted according to the method of Shan and Liang (2010). The activities of APX, GR, MDHAR, and DHAR were measured according to Nakano and Asada (1981), Grace and Logan (1996), Miyake and Asada (1992), and Dalton et al. (1986), respectively. One unit of APX activity was defined as the amount of APX catalyzing the oxidation of $1 \mu \mathrm{mol}$ of ascorbate per minute. One unit of GR activity was defined as the amount of GR catalyzing the reduction of $1 \mu \mathrm{mol}$ of NADPH per minute. One unit of MDHAR activity was defined as the amount of enzyme that oxidizes $1 \mu \mathrm{mol}$ of NADH per minute. One unit of DHAR activity was defined as the amount of enzyme that produces $1 \mu \mathrm{mol}$ of AsA per minute. Lgalactono-1,4-lactone dehydrogenase (GalLDH, EC 1.3.2.3) was extracted and measured by the method of
Tabata et al. (2001). One unit of GalLDH activity was defined as the amount of extract required to oxidize 1 nmol of L-Gal per minute. Gamma-glutamylcysteine synthetase ( $\gamma$-ECS, EC 6.3.2.2) was extracted and measured by the method of Rüegsegger and Brunold (1992). One unit of $\gamma$-ECS activity was defined as $1 \mathrm{mmol}$ of cysteine-dependently generated $\mathrm{PO}_{4}{ }^{3-}$ per minute. The specific activities of above enzymes were expressed as units $\mathrm{mg}^{-1}$ (protein) and protein content was measured according to Bradford (1976).

Total ascorbate (AsA + dehydroascorbate, DHA) was measured according to Kampfenkel et al. (1995). Samples $(0.5 \mathrm{~g})$ were extracted by $10 \mathrm{~cm}^{3}$ of $6 \%(\mathrm{~m} / \mathrm{v})$ trichloroacetic acid. AsA content was measured by using a method based on the reduction of ferric ion to ferrous ion with AsA in acidic solution followed by formation of red chelate between ferrous ion and bathophenanthroline. The absorbance of the red chelate was recorded at $525 \mathrm{~nm}$. Total ascorbate content was measured through a reduction of DHA to AsA by dithiothreitol. A standard curve prepared by using AsA and DHA was used in the calculation of the content of these metabolites.

Total glutathione (GSH + GSSG) was measured according to Griffith (1980). Samples (0.5 g) were extracted with $10 \mathrm{~cm}^{3}$ of $5 \%(\mathrm{~m} / \mathrm{v})$ sulfosalicylic acid. Total glutathione was determined by an enzymatic cycling assay method. GSSG was measured by removing GSH by 2-vinylpyridine derivatization. GSH content was then estimated from the difference between total glutathione and GSSG. A standard curve prepared by using GSH and GSSG was used in the calculation of the content of these metabolites. Malondialdehyde (MDA) content was measured by thiobarbituric acid (TBA) reaction as described by Hodges et al. (1999). Electrolyte leakage (EL) was determined according to Anjum et al. (2015).

After treatment for $7 \mathrm{~d}$, the seedlings of each treatment were harvested. Then, these seedlings were divided into shoots and roots. Fresh masses of shoots and roots were recorded and then oven dried at $80{ }^{\circ} \mathrm{C}$ for $72 \mathrm{~h}$, and dry masses were recorded. All dry samples of each treatment were ground and mixed thoroughly. To analyze the content of $\mathrm{La}$ and $\mathrm{Cd}$ in the roots and shoots, fine powder $(0.5 \mathrm{~g})$ was digested in a mixture of $7 \mathrm{~cm}^{3}$ of concentrated $\mathrm{HNO}^{3}+1 \mathrm{~cm}^{3}$ of concentrated $\mathrm{HClO}_{4}$ at $170{ }^{\circ} \mathrm{C}$ by the method of Dai et al.(2013). Subsequently, the content of $\mathrm{La}$ and $\mathrm{Cd}$ in extracts were determined by flame atomic absorbance spectrometry (Hitachi 180-80, 
Kyoto, Japan). Standard curves were prepared by using a series of diluted solutions of commercially available standards (Shenzhen City Billiton Tylenol Technology, Shenzhen, China).

\section{Results}

Compared with $\mathrm{Cd}$ stress alone, only application of $30 \mu \mathrm{M} \mathrm{LaCl}{ }_{3}$ evidently enhanced the content of reduced AsA, total AsA, reduced GSH, and total GSH under Cd stress among different concentrations of $\mathrm{LaCl}_{3}$ (Table 1). Compared with $\mathrm{Cd}$ stress alone, $30 \mu \mathrm{M} \mathrm{LaCl}{ }_{3}$ increased the content of reduced AsA, total AsA, reduced GSH and total GSH by $23.6,20.5,19.6$, and $19.7 \%$ under $\mathrm{Cd}$
The results presented are the means of six replications. Means were compared by one-way analysis of variance $(A N O V A)$ and Duncan's multiple range test at the $5 \%$ level of significance.

Table 1. Effects of $\mathrm{Cd}$ and different La concentrations on the content of reduced AsA, total AsA, reduced GSH, and total GSH in leaves of maize seedlings. The plants were pre-treated with $\mathrm{LaCl}_{3}$ for $12 \mathrm{~h}$ and then exposed to $80 \mu \mathrm{M} \mathrm{CdCl}_{2}$ for $48 \mathrm{~h}$. Means $\pm \mathrm{SEs}$, $n=6$; different letters indicate significant differences at $P \leq 0.05$.

\begin{tabular}{lllll}
\hline Treatments & $\begin{array}{l}\text { Reduced AsA } \\
{\left[\mu \mathrm{mol} \mathrm{g}{ }^{-1}(\mathrm{f} . \mathrm{m} .)\right]}\end{array}$ & $\begin{array}{l}\text { Total AsA } \\
{\left[\mu \mathrm{mol} \mathrm{g}^{-1}(\mathrm{f} . \mathrm{m} .)\right]}\end{array}$ & $\begin{array}{l}\text { Reduced GSH } \\
{\left[\mu \mathrm{mol} \mathrm{g}^{-1}(\mathrm{f} . \mathrm{m} .)\right]}\end{array}$ & $\begin{array}{l}\text { Total GSH } \\
{\left[\mu \mathrm{mol} \mathrm{g}^{-1}(\mathrm{f} . \mathrm{m} .)\right]}\end{array}$ \\
\hline Control & $2.71 \pm 0.31 \mathrm{~d}$ & $2.81 \pm 0.25 \mathrm{~d}$ & $0.48 \pm 0.04 \mathrm{c}$ & $0.50 \pm 0.06 \mathrm{c}$ \\
$80 \mu \mathrm{M} \mathrm{Cd}$ & $3.48 \pm 0.37 \mathrm{~b}$ & $3.76 \pm 0.33 \mathrm{~b}$ & $0.56 \pm 0.06 \mathrm{~b}$ & $0.61 \pm 0.06 \mathrm{~b}$ \\
$10 \mu \mathrm{M} \mathrm{La}+80 \mu \mathrm{M} \mathrm{Cd}$ & $3.70 \pm 0.37 \mathrm{~b}$ & $3.93 \pm 0.41 \mathrm{~b}$ & $0.59 \pm 0.05 \mathrm{~b}$ & $0.65 \pm 0.07 \mathrm{~b}$ \\
$30 \mu \mathrm{M} \mathrm{La}+80 \mu \mathrm{M} \mathrm{Cd}$ & $4.30 \pm 0.40 \mathrm{a}$ & $4.53 \pm 0.36 \mathrm{a}$ & $0.67 \pm 0.06 \mathrm{a}$ & $0.73 \pm 0.08 \mathrm{a}$ \\
$60 \mu \mathrm{M} \mathrm{La}+80 \mu \mathrm{M} \mathrm{Cd}$ & $3.79 \pm 0.35 \mathrm{~b}$ & $4.04 \pm 0.36 \mathrm{~b}$ & $0.60 \pm 0.07 \mathrm{~b}$ & $0.66 \pm 0.08 \mathrm{~b}$ \\
$90 \mu \mathrm{M} \mathrm{La}+80 \mu \mathrm{MCd}$ & $3.17 \pm 0.30 \mathrm{c}$ & $3.40 \pm 0.32 \mathrm{c}$ & $0.56 \pm 0.05 \mathrm{~b}$ & $0.63 \pm 0.06 \mathrm{~b}$ \\
\hline
\end{tabular}

Table 2. Effects of $\mathrm{Cd}$ and $\mathrm{La}$ on the specific activities of enzymes $\left[\mathrm{U} \mathrm{mg}^{-1}\right.$ (protein)] involved in the metabolism of AsA and GSH. The plants were pre-treated with $30 \mu \mathrm{M} \mathrm{LaCl}_{3}$ for $12 \mathrm{~h}$ and then exposed to $80 \mu \mathrm{M} \mathrm{CdCl}_{2}$ for 24 and $48 \mathrm{~h}$. Means $\pm \mathrm{SEs}, n=6$; different letters indicate significant differences at $P \leq 0.05$.

\begin{tabular}{|c|c|c|c|c|c|c|c|}
\hline Treatments & Time $[\mathrm{h}]$ & APX & GR & DHAR & MDHAR & $\gamma$-ECS & GalLDH \\
\hline \multirow[t]{2}{*}{ Control } & 24 & $1.7 \pm 0.17 \mathrm{c}$ & $1.1 \pm 0.10 \mathrm{c}$ & $1.2 \pm 0.14 \mathrm{c}$ & $1.1 \pm 0.12 b$ & $1.7 \pm 0.14 \mathrm{c}$ & $1.8 \pm 0.16 \mathrm{c}$ \\
\hline & 48 & $1.8 \pm 0.20 \mathrm{c}$ & $1.0 \pm 0.11 \mathrm{c}$ & $1.0 \pm 0.11 \mathrm{c}$ & $1.3 \pm 0.15 b$ & $1.5 \pm 0.16 \mathrm{c}$ & $2.0 \pm 0.21 \mathrm{c}$ \\
\hline \multirow[t]{2}{*}{$80 \mu \mathrm{M} \mathrm{Cd}$} & 24 & $2.2 \pm 0.20 \mathrm{~b}$ & $1.5 \pm 0.13 b$ & $1.6 \pm 0.15 b$ & $1.5 \pm 0.14 \mathrm{a}$ & $2.6 \pm 0.26 \mathrm{~b}$ & $2.5 \pm 0.22 b$ \\
\hline & 48 & $2.4 \pm 0.25 b$ & $1.7 \pm 0.16 b$ & $1.5 \pm 0.17 b$ & $1.7 \pm 0.19 \mathrm{a}$ & $2.7 \pm 0.24 b$ & $2.6 \pm 0.26 b$ \\
\hline \multirow[t]{2}{*}{$30 \mu \mathrm{M} \mathrm{La}+\mathrm{Cd}$} & 24 & $2.9 \pm 0.33 \mathrm{a}$ & $2.2 \pm 0.19 \mathrm{a}$ & $2.0 \pm 0.19 \mathrm{a}$ & $1.6 \pm 0.15 \mathrm{a}$ & $3.3 \pm 0.29 \mathrm{a}$ & $3.5 \pm 0.37 \mathrm{a}$ \\
\hline & 48 & $2.8 \pm 0.25 \mathrm{a}$ & $2.2 \pm 0.24 \mathrm{a}$ & $2.1 \pm 0.23 \mathrm{a}$ & $1.6 \pm 0.18 \mathrm{a}$ & $3.5 \pm 0.33 \mathrm{a}$ & $3.3 \pm 0.32 \mathrm{a}$ \\
\hline
\end{tabular}

Table 3. Effects of $\mathrm{Cd}$ and $\mathrm{La}$ on the content of reduced AsA, total AsA, reduced GSH, and total GSH [ $\mu \mathrm{mol} \mathrm{g}^{-1}$ (f.m.)] in maize leaves. The plants were pre-treated with $30 \mu \mathrm{M} \mathrm{LaCl}_{3}$ for $12 \mathrm{~h}$ and then exposed to $80 \mu \mathrm{M} \mathrm{CdCl}_{2}$ for 24 and $48 \mathrm{~h}$. Means $\pm \mathrm{SEs}$, $n=6$; different letters indicate significant differences at $P \leq 0.05$.

\begin{tabular}{|c|c|c|c|c|c|}
\hline Treatments & Time $[\mathrm{h}]$ & Reduced AsA & Total AsA & Reduced GSH & Total GSH \\
\hline \multirow[t]{2}{*}{ Control } & 24 & $2.75 \pm 0.30 c$ & $2.90 \pm 0.27 \mathrm{c}$ & $0.45 \pm 0.04 c$ & $0.47 \pm 0.05 c$ \\
\hline & 48 & $2.97 \pm 0.28 c$ & $3.10 \pm 0.33 c$ & $0.42 \pm 0.05 c$ & $0.44 \pm 0.04 c$ \\
\hline \multirow[t]{2}{*}{$80 \mu \mathrm{M} \mathrm{Cd}$} & 24 & $3.53 \pm 0.36 b$ & $3.80 \pm 0.40 b$ & $0.55 \pm 0.05 b$ & $0.61 \pm 0.06 b$ \\
\hline & 48 & $3.49 \pm 0.31 b$ & $3.77 \pm 0.35 b$ & $0.53 \pm 0.06 b$ & $0.60 \pm 0.07 b$ \\
\hline \multirow[t]{2}{*}{$30 \mu \mathrm{M} \mathrm{La}+\mathrm{Cd}$} & 24 & $4.13 \pm 0.38 \mathrm{a}$ & $4.02 \pm 0.39 a$ & $0.66 \pm 0.08 \mathrm{a}$ & $0.71 \pm 0.08 \mathrm{a}$ \\
\hline & 48 & $4.40 \pm 0.42 \mathrm{a}$ & $4.31 \pm 0.37 \mathrm{a}$ & $0.68 \pm 0.06 \mathrm{a}$ & $0.73 \pm 0.07 \mathrm{a}$ \\
\hline
\end{tabular}


significantly increased the activities of above enzymes except MDHAR and the content of above metabolites in stressed leaves. After treatment of $48 \mathrm{~h}, \mathrm{La}+\mathrm{Cd}$ increased the activities of APX, GR, DHAR, $\gamma$-ECS, and GalLDH by $16.7,29.4,40.0,29.6$, and $26.9 \%$, respectively. Meanwhile, $\mathrm{La}+\mathrm{Cd}$ increased the content of reduced AsA, reduced GSH, total AsA, and total GSH by $26.1,28.3,14.3$, and $21.7 \%$, respectively. These results indicated that La could regulate the metabolism of AsA and GSH in the leaves of maize seedlings under $\mathrm{Cd}$ stress.

Compared with control, Cd evidently increased MDA content and EL by 120.3 and $153.9 \%$, respectively. Compared with Cd stress alone, $\mathrm{La}+\mathrm{Cd}$ decreased MDA content and EL by 30 and $29.6 \%$, respectively (Table 4 ). These results indicated that La had important role in the acquisition of the $\mathrm{Cd}$ tolerance of maize seedlings.

The application of $\mathrm{Cd}$ significantly increased $\mathrm{Cd}$ content in both roots and shoots. Compared with control, $\mathrm{Cd}$ stress increased $\mathrm{Cd}$ content in roots and shoots by 53.3- and 62-fold, respectively. Compared with Cd stress alone, $\mathrm{La}+\mathrm{Cd}$ significantly decreased $\mathrm{Cd}$ content in roots and shoots by 36.5 and $28.6 \%$, respectively. These
Table 4. Effects of Cd and La on MDA content and EL of maize leaves. The plants were pre-treated with $30 \mu \mathrm{M} \mathrm{LaCl}_{3}$ for $12 \mathrm{~h}$ and then exposed to $80 \mu \mathrm{M} \mathrm{CdCl}_{2}$ for $48 \mathrm{~h}$. Means $\pm \mathrm{SEs}, n=6$; different letters indicate significant differences at $P \leq 0.05$.

\begin{tabular}{lcl}
\hline Treatments & MDA $\left[\mathrm{nmol} \mathrm{g}^{-1}\right.$ (f.m.) $]$ & EL [\%] \\
\hline Control & $5.9 \pm 0.72 \mathrm{c}$ & $10.2 \pm 1.27 \mathrm{c}$ \\
$80 \mu \mathrm{M} \mathrm{Cd}$ & $13.0 \pm 1.13 \mathrm{a}$ & $25.9 \pm 2.25 \mathrm{a}$ \\
$30 \mu \mathrm{M} \mathrm{La}+\mathrm{Cd}$ & $9.1 \pm 1.03 \mathrm{~b}$ & $18.2 \pm 1.64 \mathrm{~b}$ \\
\hline
\end{tabular}

results indicated that La can decrease the accumulation of $\mathrm{Cd}$ in maize seedlings.

To further investigate whether La can alleviate the $\mathrm{Cd}$ toxicity, the effect of La on the dry biomass of roots and shoots under $\mathrm{Cd}$ stress was studied. Compared with control, $\mathrm{Cd}$ decreased the dry mass of roots and shoots by 35.1 and $28.2 \%$, respectively (Table 5). Compared with $\mathrm{Cd}$ stress alone, $\mathrm{La}+\mathrm{Cd}$ evidently increased the dry biomass of roots and shoots by 29.2 and $17.9 \%$, respectively. These results indicated that La can alleviate the Cd toxicity of maize seedlings.

Table 5. Effects of $\mathrm{Cd}$ and $\mathrm{La}$ application on the content of $\mathrm{La}$ and $\mathrm{Cd}$, and the dry mass of roots and shoots of maize seedlings. The plants were pre-treated with $30 \mu \mathrm{M} \mathrm{LaCl}_{3}$ for $12 \mathrm{~h}$ and then exposed to $80 \mu \mathrm{M} \mathrm{CdCl}_{2}$ for $7 \mathrm{~d}$. Means $\pm \mathrm{SEs}, n=6$; different letters indicate significant differences at $P \leq 0.05$.

\begin{tabular}{|c|c|c|c|c|c|c|}
\hline \multirow[t]{2}{*}{ Treatments } & \multicolumn{2}{|l|}{$\mathrm{La}\left[\mathrm{mg} \cdot \mathrm{kg}^{-1}(\mathrm{~d} . \mathrm{m}).\right]$} & \multicolumn{2}{|c|}{$\mathrm{Cd}\left[\mathrm{mg} \cdot \mathrm{kg}^{-1}(\mathrm{~d} . \mathrm{m}).\right]$} & \multicolumn{2}{|l|}{$\left.\mathrm{DM}\left[\mathrm{g} \cdot \mathrm{plant}^{-1}\right)\right]$} \\
\hline & shoot & root & shoot & root & shoot & root \\
\hline Control & $0.01 \pm 0.00 \mathrm{~b}$ & $0.05 \pm 0.00 \mathrm{~b}$ & $0.1 \pm 0.00 \mathrm{c}$ & $0.3 \pm 0.00 \mathrm{c}$ & $1.56 \pm 0.17 \mathrm{a}$ & $0.37 \pm 0.04 a$ \\
\hline $80 \mu \mathrm{M} \mathrm{Cd}$ & $0.02 \pm 0.00 b$ & $0.08 \pm 0.00 \mathrm{~b}$ & $6.3 \pm 0.61 \mathrm{a}$ & $16.4 \pm 0.20 \mathrm{a}$ & $1.12 \pm 0.11 \mathrm{c}$ & $0.24 \pm 0.02 \mathrm{c}$ \\
\hline $30 \mu \mathrm{M} \mathrm{La}+\mathrm{Cd}$ & $42.50 \pm 5.51 \mathrm{a}$ & $401.90 \pm 25.99 a$ & $4.0 \pm 0.35 b$ & $11.7 \pm 0.13 b$ & $1.32 \pm 0.15 b$ & $0.31 \pm 0.04 \mathrm{~b}$ \\
\hline
\end{tabular}

\section{Discussion}

Increasing concentrations of $\mathrm{Cd}$ could induce oxidative damage in plants (Tamas et al. 2015). In our study, an enhanced lipid peroxidation indicated by MDA content and EL was observed in maize leaves under Cd stress, which suggested that $\mathrm{Cd}$ stress also induced oxidative stress to maize seedlings. Wu et al. (2015) documented that plants could protect themselves against $\mathrm{Cd}$ stress by increasing the activities of APX, GR, and DHAR, and the content of reduced GSH and reduced AsA. Guan et al. (2015) reported that $\mathrm{Cd}$ induced the expression of GSH1 and GSH2 genes, and the content of reduced GSH in tobacco. In the present study, our results showed that $\mathrm{Cd}$ stress could increase the activities of APX, GR, and DHAR, and the content of reduced AsA and reduced GSH in leaves of maize seedlings. Besides, we found that $\mathrm{Cd}$ stress enhanced the activities of MDHAR, GalLDH, and $\gamma$-ECS involved in AsA and GSH metabolism and the content of total AsA and total GSH in maize leaves.
It has been proved that low concentrations of La can relieve oxidative damage in plants exposed to $\mathrm{Cd}$ stress, but higher La concentrations may enhance oxidative damage in plants exposed to Cd stress (Wang et al. 2012). However, there is still very little knowledge about the regulation of the AsA and GSH metabolism by La under Cd stress. AsA has important role in stress defense (Arafa et al. 2009, Khafagy et al. 2009). The cellular content of AsA can be determined by GalLDH, DHAR, MDHAR, and APX activities. It has been documented that La increased the activity of APX in Saussurea involucrata under salt stress and in Vicia faba seedlings under Cd stress (Xu et al. 2007, Wang et al. 2012). Zhang et al. (2003) reported that La could enhance the activities of APX and DHAR in the leaves of wheat. In the present study, we found that La also increased the activities of APX and DHAR in maize seedlings under Cd stress. Besides, our study also showed that La increased the 
activity of GalLDH, and the content of reduced AsA and total AsA under Cd stress. However, our results showed that La did not affect the MDHAR activity in maize seedlings under $\mathrm{Cd}$ stress, which was consistent with the results of Zhang et al. (2003). So, La could regulate the regeneration of AsA through APX and DHAR and the synthesis of AsA through GalLDH in maize seedlings under Cd stress.

GSH is another important compound of plant antioxidant system. The cellular content of GSH can be determined by $\gamma$-ECS and GR. It has been documented that La increased the activity of GR in Saussurea involucrata under salt stress (Xu et al. 2007). Our previous study showed that La increased the activity of $\gamma$-ECS and GR in Vigna radiata seedlings under salt stress (Shan and Zhao 2014). However, Zhang et al. (2003) reported that La did not affect the activity of GR in wheat. Above difference may be due to the difference in species. The results of our present study also showed that La could regulate the glutathione metabolism by increasing the activity of $\gamma$-ECS and GR, which was consistent with previous studies. Besides, our study also indicated that La increased the content of reduced GSH and total GSH under Cd stress.

It has been reported that up to $5 \mu \mathrm{M} \mathrm{La}$ had no effect on maize biomass but decreased mungbean biomass (Diatloff et al. 2008). In other study, La had also no effect on the growth of maize seedlings ( $\mathrm{Hu}$ et al. 2006). However, Liu et al. (2013) reported that low concentrations of La could enhance the growth of rice seedlings, while high concentrations of La inhibited the growth of rice seedlings. Under Cd stress, Babula et al. (2015) reported that $\mathrm{La}$ decreased the biomass of
Hypericum perforatum. However, our findings showed that $30 \mu \mathrm{M}$ La could increase the dry biomass of maize seedlings under Cd stress. Further, La decreased the content of reduced AsA and increased the content of reduced GSH in $H$. perforatum. However, we found that La increased the content of reduced AsA and reduced GSH content in maize. In the ascorbate-glutathione cycle, the decrease in the content of reduced AsA induced by La inhibited the activity of this cycle in $H$. perforatum. In order to defend against oxidative stress, $H$. perforatum used reduced GSH as an alternative to scavenge ROS through glutathione peroxidase. So, reduced GSH could not be used to chelate $\mathrm{Cd}$ any longer in $H$. perforatum. La increased the content of reduced AsA, enhanced the activity of the ascorbate-glutathione cycle, and the ability to defend against oxidative stress induced by $\mathrm{Cd}$ stress. So, reduced GSH increased by $\mathrm{La}$ could be used to chelate $\mathrm{Cd}$ in maize seedlings. For above reason, La enhanced the growth of maize seedlings in this study but inhibited the growth of $H$. perforatum under $\mathrm{Cd}$ stress. This interpretation can be also proved by $\mathrm{Cd}$ content in $H$. perforatum and maize seedlings. For $H$. perforatum, La significantly increased $\mathrm{Cd}$ content in shoots under $\mathrm{Cd}$ stress. However, La significantly decreased $\mathrm{Cd}$ content in both roots and shoots of maize seedlings under Cd stress in our study. As the Cd toxicity to plants is due to its over-accumulation in tissues. So, in the present study, La increased the biomass of maize seedlings under Cd stress.

Our results clearly imply that La can improve the $\mathrm{Cd}$ tolerance of maize seedlings by regulating the metabolism of AsA and GSH, which provide new knowledge for the role of $\mathrm{La}$ in regulating the $\mathrm{Cd}$ tolerance of plants.

\section{References}

Anjum, S.A., Tanveer, M., Hussain, S., Bao, M., Wang, L., Khan, I., Ullah, E., Tung, S.A., Samad, R.A., Shahzad, B.: Cadmium toxicity in maize (Zea mays L.): consequences on antioxidative systems, reactive oxygen species and cadmium accumulation. - Environ. Sci. Pollut. Res. 22: 17022-17030, 2015.

Arafa, A.A., Khafagy, M.A., El-Banna, M.F.: The effect of glycinebetaine or ascorbic acid on grain germination and leaf structure of sorghum plants grown under salinity stress. - Aust. J. Crop Sci. 3: 294-304, 2009.

Babula, P., Klejdus, B., Kovacik, J., Hedbavny, J., Hlavna, M.: Lanthanum rather than cadmium induces oxidative stress and metabolite changes in Hypericum perforatum. - J. Hazard. Mater. 286: 334-342, 2015.

Bradford, M.M.: A rapid and sensitive method for the quantitation of microgram quantities of protein utilizing the principle of protein-dye binding. - Anal. Biochem. 72: 248254, 1976.

Dai, H., Shan, C., Jia, G., Yang, T., Wei, A., Zhao, H., Wu, S., Huo, K., Chen, W., Cao, X.: Responses to cadmium: tolerance, accumulation and translocation in Populus $\times$ canescens. - Water Air Soil Pollut. 224: 1504-1512, 2013.
Dalton, D.A., Russell, S.A., Hanus, F.J., Pascoe, G.A., Evans, H.J.: Enzymatic reactions of ascorbate and glutathione that prevent peroxide damage in soybean root nodules. - Proc. nat. Acad. Sci. USA 83: 3811-3815, 1986.

Daud, M.K., Mei, L., Azizullah, A., Dawood, M., Ali, I., Mahmood, Q., Ullah, W., Jamil, M., Zhu, S.J.: Leaf-based physiological, metabolic, and ultrastructural changes in cultivated cotton cultivars under cadmium stress mediated by glutathione. - Environ. Sci. Pollut. Res. DOI: 10.1007/s11356-016-6739-5, 2016.

Diatloff, E., Smith, F.W., Asher, C.J.: Effects of lanthanum and cerium on the growth and mineral nutrition of corn and mungbean. - Ann. Bot. 101: 971-982, 2008.

Grace, S.C., Logan, B.A.: Acclimation of foliar antioxidant systems to growth irradiance in three broad-leaved evergreen species. - Plant Physiol. 112: 1631-1640, 1996.

Griffith, O.W.: Determination of glutathione and glutathione disulfide using glutathione reductase and 2-vinylpyridine. Anal. Biochem. 106: 207-212, 1980.

Guan, C.F., Ji, J., Wu, D.Y., Li, X.Z., Jin, C., Guan, W.Z., Wang, G.: The glutathione synthesis may be regulated by cadmium-induced endogenous ethylene in Lycium chinense, 
and overexpression of an ethylene responsive transcription factor gene enhances tolerance to cadmium stress in tobacco. - Mol. Breed. 35: 123, 2015.

Guo, B., Xu, L., Guan, Z., Wei, Y.: Effect of lanthanum on rooting of in vitro regenerated shoots of Saussurea involucrata Kar. et Kir. - Biol. Trace Element Res. 147: 334-340, 2012.

Hodges, M.D., DeLong, J.M., Forney, C.F., Prange, R.K.: Improving the thiobarbituric acid-reactive-substances assay for estimating lipid peroxidation in plant tissues containing anthocyanin and other interfering compounds. - Planta 207: 604-611, 1999.

Hong, F., Wang, L., Liu, C.: Study of lanthanum on seed germination and growth of rice. - Biol. Trace Element Res. 94: 273-286, 2003.

$\mathrm{Hu}, \mathrm{X}$., Wang, X., Wang, C.: Bioaccumulation of lanthanum and its effect on growth of maize seedlings in a red loamy soil. - Pedosphere 16: 799-805, 2006.

Kampfenkel, K., Van Montagu, M., Inze, D.: Effects of iron excess on Nicotiana plumbaginifolia plants (implications to oxidative stress). - Plant Physiol. 107: 725-735, 1995.

Khafagy, M.A., Arafa, A.A., El-Banna, M.F.: Glycinebetaine and ascorbic acid can alleviate the harmful effects of $\mathrm{NaCl}$ salinity in sweet pepper. - Aust. J. Crop Sci. 3: 257-267, 2009.

Liu, D., Wang, X., Zhang, X., Gao, Z.: Effects of lanthanum on growth and accumulation in roots of rice seedlings. - Plant Soil Environ. 5: 196-200, 2013.

Miyake, C., Asada, K.: Thylakoid-bound ascorbate peroxidase in spinach chloroplasts and photoreduction of its primary oxidation product monodehydroascorbate radicals in thylakoids. - Plant Cell Physiol. 33: 541-553, 1992.

Naiija, A., Marchand, J., Kestemont, P., Haouas, Z., Blust, R., Chénais, B., Helal, A.N.: Biomarkers assessment in the peacock blenny Salaria pavo exposed to cadmium. Environ. Sci. Pollut. Res. DOI:10.1007/s11356-016-6754-6, 2016.

Nakano, Y., Asada, K.: Hydrogen peroxide is scavenged by ascorbate specific peroxidase in spinach chloroplasts. Plant Cell Physiol. 22: 867-880, 1981.

Rüegsegger, A., Brunold, C. Effect of cadmium on $\gamma$ glutamylcysteine synthesis in maize seedlings. - Plant
Physiol. 99: 428-433, 1992.

Shan, C., He, F., Xu, G., Han, R., Liang, Z.: Nitric oxide is involved in the regulation of ascorbate and glutathione metabolism in Agropyron cristatum leaves under water stress. - Biol. Plant. 56: 187-191, 2012.

Shan, C., Liang, Z.: Jasmonic acid regulates ascorbate and glutathione metabolism in Agropyron cristatum leaves under water stress. - Plant Sci. 178: 130-139, 2010.

Shan, C., Zhao, X.: Effects of lanthanum on the ascorbate and glutathione metabolism of Vigna radiata seedlings under salt stress. - Biol. Plant. 58: 595-599, 2014.

Tabata, K., Oba, K., Suzuki, K., Esaka, M.: Generation and properties of ascorbic acid-deficient transgenic tobacco cells expressing antisense RNA of L-galactono-1,4-lactone dehydrogenase. - Plant J. 27: 139-148, 2001.

Tamas, L., Mistrik, I., Alemayehu, A., Zelinova, V., Bocova, B., Huttova, J.: Salicylic acid alleviates cadmium-induced stress responses through the inhibition of Cd-induced auxinmediated reactive oxygen species production in barley root tips. - J. Plant Physiol. 173: 1-8, 2015.

Wang, C.R., Xiao, J.J., Tian, Y., Bao, X., Liu, L., Yu, Y., Wang, X.R., Chen, T.Y.: Antioxidant and prooxidant effects of lanthanum ions on Vicia faba L. seedlings under cadmium stress, suggesting ecological risk. - Environ. Toxicol. Chem. 31: 1355-1362, 2012.

Wu, Z.C., Zhao, X.H., Sun, X.C., Tan, Q.L., Tang, Y.F., Nie, Z.J., Qu, C.J., Chen, Z.X., Hu, C.X.: Antioxidant enzyme systems and the ascorbate-glutathione cycle as contributing factors to cadmium accumulation and tolerance in two oilseed rape cultivars (Brassica napus L.) under moderate cadmium stress. - Chemosphere 138: 526-536, 2015.

$\mathrm{Xu}$, C.M., Zhao, B., Wang, X.D., Wang, Y.C.: Lanthanum relieves salinity-induced oxidative stress in Saussurea involucrate. - Biol. Plant. 51: 567-570, 2007.

Zhang, L., Zeng, F., Xiao, R.: Effect of lanthanum ions $\left(\mathrm{La}^{3+}\right)$ on the reactive oxygen species scavenging enzymes in wheat leaves. - Biol. Trace Element Res. 91: 243-252, 2003.

Zhou, J., Fang, L., Li, X., Guo, L., Huang, L.: Jasmonic acid (JA) acts as a signal molecule in $\mathrm{LaCl}_{3}$-induced baicalin synthesis in Scutellaria baicalensis seedlings. - Biol. Trace Element Res. 148: 392-395, 2012. 